\title{
AN EVALUATION OF THE RESPIRATORY CAPACITY OF HUMAN SPERMATOZOA
}

\author{
R. N. PETERSON AND M. FREUND \\ Laboratory of Reproductive Pharmacology, Departments of Pharmacology and of Obstetrics \\ and Gynecology, New York Medical College, Flower and Fifth Avenue Hospitals, \\ New York, U.S.A.
}

(Received 5th December 1967, revised 11th March 1968)

Summary. The level of human sperm respiration in semen and in artificial media has been estimated by manometric and radiochemical techniques. Our results show that the respiration is small, exhibiting rates that rarely exceed 1 to $2 \mu \mathrm{l} / 10^{8}$ cells $/ \mathrm{hr}$. These low $\mathrm{Zo}_{2}$ values and the limited sensitivity of the manometric apparatus stress the point that pooled specimens with high cell concentrations must be used in order to obtain reliable estimates of oxygen consumption. Attention is also drawn to the fact that measurements of oxygen uptake by cells in whole semen are further complicated by the high rates and variability of oxygen absorption by seminal plasma and that small errors in the estimation of this absorption can lead to substantial errors in estimates of cellular oxygen uptake. Although isotopic measurements of respiration are more sensitive than manometric techniques, some reserve is also required when interpreting results based on ${ }^{14} \mathrm{CO}_{2}$ evolution alone. Experiments with $\left[\mathrm{U}_{-1}{ }^{14} \mathrm{C}\right]$ glucose and $\left[6-{ }^{14} \mathrm{C}\right]$ glucose indicate that the carbon atoms of glucose are not converted to $\mathrm{CO}_{2}$ in an identical manner. The higher rates of ${ }^{14} \mathrm{CO}_{2}$ produced from the metabolism of uniformly labelled glucose suggest that a portion of the glucose molecule may be converted to $\mathrm{CO}_{2}$ through non-oxidative pathways. In view of such a possibility, the ability of washed cells and whole semen to convert $\left[6-{ }^{14} \mathrm{C}\right]$ glucose into labelled $\mathrm{CO}_{2}$ provides less equivocal radiochemical evidence than that previously reported for true respiratory activity in human sperm cells. High phosphate concentrations inhibit the conversion of glucose to carbon dioxide. It is suggested that this may represent the presence of competing reactions for limiting intermediates involved in glycolytic and respiratory pathways. We have also described the use of the rapid Millipore filtration technique to follow glucose uptakes and incorporation into acid-insoluble (lipid) components of sperm cells. Uptake into acid-insoluble compounds is rapid and represents a substantial portion of the radio-active glucose that is retained by cells. The potential usefulness of this method to measure endogenous lipid turnover and the role of cellular lipid in endogenous respiration is also considered. 


\section{INTRODUCTION}

The demonstration of cytochrome pigments in human sperm by Mann (1951) indicated that these cells possess a potential respiratory capacity. However, the extent to which this capacity is expressed has been a matter of controversy because of the conflicting results of manometric studies on oxygen uptake by semen and washed spermatozoa. In early studies with semen, Shettles (1940) reported a high respiratory rate with $\mathrm{Zo}_{2}$ values $\left(\mu \mathrm{l} / 10^{8}\right.$ spermatozoa/hr) between 6 and 10 and no oxygen uptake by the cell-free plasma. However, MacLeod (1941, 1943) observed a much smaller respiration by spermatozoa in a plasma-free medium with $\mathrm{Zo}_{2}$ values between 1 and 2, which led him to suggest that oxygen uptake by semen is due solely to the seminal plasma. Ross, Miller \& Kurzrok (1941) applied an average correction for plasma oxygen uptake and obtained $\mathrm{Zo}_{2}$ values between 0 and 13. Davis \& McCune (1950) reported an average $\mathrm{Zo}_{2}$ of 11 for semen, but the values were not corrected for scminal plasma oxygen uptake. Using a calorimeter method, Rothschild (1960) concluded that human spermatozoa were capable of respiration but at a lower rate than bull spermatozoa. However, Williams \& Hamner (1963) reported high $\mathrm{ZO}_{2}$ values $(>10)$ both for semen and for washed cell suspensions. On the other hand, Terner (1960) was unable to obtain any manometric readings with washed sperm suspensions but was able to demonstrate the capacity of washed cells and semen to oxidize labelled glucose, pyruvate and acetate. The conflicting reports cited above have led to a re-evaluation of the manometric method as applied to the measurement of human sperm respiration.

\section{METHODS}

Semen characteristics were determined by the methods that are standard in this laboratory (Freund, 1962, 1963); sperm counts were made in quadruplicate as described by Freund \& Carol (1964). In some experiments pooled semen was used; in other experiments cells were separated from plasma by centrifugation ( $270 \mathrm{~g}$ for $10 \mathrm{~min}$ ), washed twice with a balanced salts medium (see below), and resuspended in the medium. The motility of spermatozoa in semen, rated at $37^{\circ} \mathrm{C}$, varied between 50 and $70 \%$, while motilities after washing varied between 30 and $50 \%$.

Two low phosphate media were used, since it has been noted (White, 1954) that human spermatozoa rapidly lose motility upon dilution with phosphate diluents. It has also been found (MacLeod \& Freund, 1958; Freund \& MacLeod, 1958; Rothschild, 1960) that dilution of human semen with 0.25 Mdisodium phosphate or with a more complex phosphate buffer resulted in a reduction of metabolism and motility. Norman-Johnson-Solution 2 (N-J-2) (Norman, 1964) was used in some experiments since experience (Freund \& Wiederman, 1966) has shown this medium to be superior for maintaining the motility of human spermatozoa. This is a citrate based medium containing 0.0734 M-sodium citrate; 0.0204 M-calcium chloride; 0.0018 M-magnesium chloride; $0.0024 \mathrm{M}$-sodium chloride; $0.0028 \mathrm{M}$-potassium chloride; and 0.0002 $\mathrm{M}$-monosodium phosphate. The $\mathrm{pH}$ is 7.7 but the buffering capacity is low at physio- 
logical $\mathrm{pH}$. A more adequately buffered medium was used in other experiments; this medium contained $0.140 \mathrm{M}$-sodium chloride; $0.003 \mathrm{M}$-potassium chloride; $0.003 \mathrm{M}$-magnesium sulphate; $0.0042 \mathrm{M}$-disodium phosphate; and $0.00085 \mathrm{M}$ monosodium phosphate and the $\mathrm{pH}$ was $7 \cdot 4$. Sperm motility remained high ( 50 to $60 \%$ ) after two washes with this medium. Both media were supplemented with glucose at a concentration dictated by the purpose of a particular experiment.

\section{Manometric measurements}

Single-arm Warburg manometers and horizontal capillary differential syringe manometers were used to measure oxygen uptake by raw semen and by washed cell suspensions. A discussion of the advantages of the latter apparatus has been reported (Peterson, Freund \& Gilmont, 1967). For measurements with the single-arm manometer, seven experiments were run. Each experiment consisted of six determinations: three flasks containing semen and three flasks containing sperm-free seminal plasma, taken from the same pooled specimen. Sperm-free seminal plasma was prepared by centrifuging at $1500 \mathrm{~g}$ for $15 \mathrm{~min}$. Each Warburg flask $(15 \mathrm{ml}$ capacity) contained $3.0 \mathrm{ml}$ raw semen (or 3.0 $\mathrm{ml}$ sperm-free plasma), $0.3 \mathrm{ml}$ White's phosphate, and penicillin. Centre wells contained $0.2 \mathrm{ml} 10 \% \mathrm{KOH}$ and a folded strip of filter paper. The temperature was $37^{\circ} \mathrm{C}$ and the gas phase was air. Four measurements of oxygen consumption by spermatozoa resuspended in seminal plasma were run with the differential manometer apparatus. The pooled specimen was centrifuged (270 $\boldsymbol{g}$ for $10 \mathrm{~min}$ ) and the cells resuspended in a smaller volume of supernatant seminal plasma. The sperm-seminal plasma suspension $(2.0$ to $2.4 \mathrm{ml})$ was added to a Warburg flask ( $6 \mathrm{ml}$ capacity) and an equal volume of sperm-free seminal plasma was added to the control arm flask. Centre wells in both flasks contained $0.1 \mathrm{ml} 20 \% \mathrm{KOH}$ and folded filter paper strips. Measurements were made at $37^{\circ} \mathrm{C}$ with air as gas phase. Experiments with washed cell suspensions were carried out identically; the control arms contained an equal volume of the suspending medium in place of the sperm suspension.

\section{$\mathrm{CO}_{2}$ measurements}

${ }^{14} \mathrm{CO}_{2}$ arising from $\left[\mathrm{U}-{ }^{14} \mathrm{C}\right]$ glucose and $\left[6-{ }^{14} \mathrm{C}\right]$ glucose was collected using a gas train similar to that described by Baggioline \& Bickel (1966). Cell suspensions were incubated in scintillation vials at $37^{\circ} \mathrm{C}$ with magnetic stirring. Vials were connected in series by plastic tubing through a cold trap into vials containing $3 \mathrm{ml} 0.01 \mathrm{~N}-\mathrm{KOH}$. Vacuum lines were used to draw streams of water-saturated air over the cell suspensions and to carry evolved $\mathrm{CO}_{2}$ into the collection vials. After the $\mathrm{CO}_{2}$ was collected, the vials were dried at $110^{\circ} \mathrm{C}$, the residue was dissolved in $0.3 \mathrm{ml}$ distilled water, $10 \mathrm{ml}$ Bray's scintillation fluid was added and vials were counted in a Nuclear Chicago liquid scintillation counter. Counting efficiencies varied between 60 and $70 \%$. This collection procedure offers an advantage over that employed by Baggioline \& Bickel since the ethanolamine-methanol absorbent used by these workers causes considerable quenching in either toluene or Bray's scintillation fluid; this quenching reduced counting efficiencies to below $20 \%$. An important 


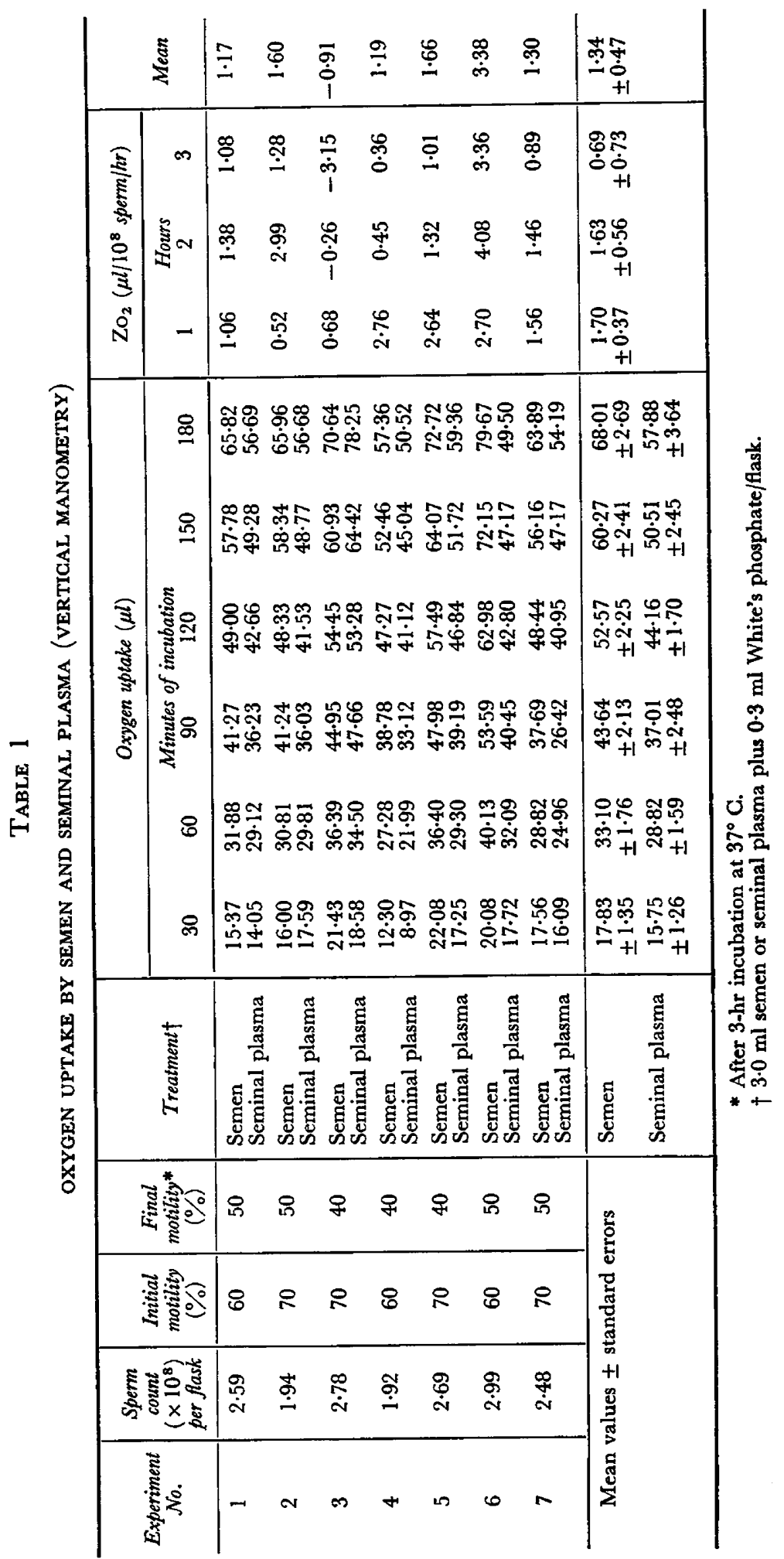


advantage of the gas train method was that background counts in controls (isotope in absence of cells) were reduced to zero. Experience indicated that high background counts are difficult to avoid using Warburg flasks in which alkali-soaked filter paper strips are placed in centre wells to absorb labelled carbon dioxide evolved. An assay of ${ }^{14} \mathrm{CO}_{2}$ production from the metabolism of $\left[\mathrm{U}-{ }^{14} \mathrm{C}\right]$ glucose carried out in triplicate with the gas train from the same cell suspension gave a standard deviation which was $5 \%$ of the mean.

\section{Measurement of cellular uptake of radio-active glucose}

The time course of radio-active glucose uptake was measured by rapid Millipore filtration (Britten, Roberts \& French, 1955); 0.4-ml aliquots of washed cells suspensions, incubated in the presence of the radio-active substrate, were removed and the cells collected on membrane filters (Millipore type HA, $0 \cdot 8 \mu$ pore size, $25 \mathrm{~mm}$ diam). The filters were washed with three $3-\mathrm{ml}$ volumes of medium before being placed in scintillation vials, dried and counted. Uptake into acid-insoluble compounds was determined by adding $0 \cdot 4-\mathrm{ml}$ aliquots of cell suspension to tubes containing an equal volume of cold $10 \%$ trichloracetic acid. After $30 \mathrm{~min}$, the acid-insoluble material was collected on Millipore filters and dried in scintillation vials at $100^{\circ} \mathrm{C}$ for $15 \mathrm{~min}$. Bray's scintillation fluid $(10 \mathrm{ml})$ was added to the vial which was then counted.

\section{Lactate determination}

Lactic acid, produced by washed cell suspensions metabolizing glucose, was determined enzymatically with lactic dehydrogenase and diphosphopyridine nucleotide. These determinations were made on duplicate aliquots of medium from which cells had been removed by Millipore filtration.

\section{Manometric measurements}

\section{RESULTS}

The results of measurements of oxygen consumption by spermatozoa suspended in seminal plasma, as determined by both vertical single-arm manometry and horizontal capillary differential manometry, are shown in Tables 1 and 2, respectively. The $\mathrm{Zo}_{2}$ values indicate that cellular oxygen

TABLE 2

DIFFERENTIAL MANOMETRIC MEASUREMENTS OF OXYGEN CONSUMPTION BY HUMAN SPERMATOZOA SUSPENDED IN SEMINAL PLASMA AT $37^{\circ} \mathrm{G}$

\begin{tabular}{|c|c|c|c|c|c|c|c|}
\hline \multirow{2}{*}{ Temperature } & \multirow{2}{*}{$\begin{array}{c}\text { Experiment } \\
\text { no. }\end{array}$} & \multirow{2}{*}{$\begin{array}{c}\text { Sperm count } \\
\left(\times 10^{8}\right) \\
\text { per flask }\end{array}$} & \multirow{2}{*}{$\begin{array}{l}\text { Initial } \\
\text { motility } \\
(\%)\end{array}$} & \multicolumn{4}{|c|}{$\mathrm{Zo}_{2}$} \\
\hline & & & & 1 & $\begin{array}{c}\text { Hours } \\
2\end{array}$ & 3 & Mean \\
\hline $37^{\circ} \mathrm{C}$ & $\begin{array}{l}1 \\
2 \\
2 \\
3\end{array}$ & $\begin{array}{l}0.90 \\
1.75 \\
1.50 \\
2.58\end{array}$ & $\begin{array}{l}60 \\
60 \\
60 \\
50\end{array}$ & $\begin{array}{c}2.33 \\
-1.65 \\
0.670 \\
-0.78\end{array}$ & $\begin{array}{r}1 \cdot 00 \\
2 \cdot 40 \\
5 \cdot 20 \\
-0 \cdot 78\end{array}$ & $\begin{array}{r}1.00 \\
2 \cdot 80 \\
4 \cdot 13 \\
-0 \cdot 78\end{array}$ & $\begin{array}{r}1.44 \\
1.18 \\
3.33 \\
-0.78\end{array}$ \\
\hline \multicolumn{4}{|l|}{ Mean values } & $0 \cdot 14$ & 1.96 & 1.79 & 1.29 \\
\hline
\end{tabular}


consumption by semen is small with an hourly average value of 1.3 for the 3-hr period. The standard errors of the mean, however, are large which may reflect metabolic differences in the pooled specimens (see discussion below). The standard error is probably also increased as a result of corrections that must be made due to the large amount of oxygen taken up by seminal plasma. The data in Table 1 emphasize that high cell counts are required to obtain reproducible manometric estimates of oxygen consumption. Since the cell count in single ejaculates seldom exceeds $10^{8}$ cells (Freund, 1962, 1963; Freund \& Carol, 1964), a consideration of the $\mathrm{Zo}_{2}$ values reported here shows that such individual specimens would, on the average, consume less than 4 to 5 $\mu \mathrm{l}$ of oxygen over a 3 -hr period. This level of oxygen uptake is too low to be reproducibly estimated by manometric apparatus in current use.

\section{TABLE 3}

DIFFERENTIAL MANOMETRIG MEASUREMENTS OF OXYGEN CONSUMPTION BY WASHED HUMAN SPERMATOZOA SUSPENDED IN NORMAN-JOHNSON-SOLUTION 2

\begin{tabular}{|c|c|c|c|c|c|c|c|}
\hline \multirow{2}{*}{ Temperature } & \multirow{2}{*}{$\begin{array}{l}\text { Experiment } \\
\text { no. }\end{array}$} & \multirow{2}{*}{$\begin{array}{c}\text { Sperm count } \\
\left(\times 10^{8}\right) \\
\text { per flask }\end{array}$} & \multirow{2}{*}{$\begin{array}{l}\text { Initial } \\
\text { motility } \\
(\%)\end{array}$} & \multicolumn{4}{|c|}{$\mathrm{Zo}_{2}$} \\
\hline & & & & 1 & $\begin{array}{c}\text { Hours } \\
2\end{array}$ & 3 & Mean \\
\hline $25^{\circ} \mathrm{C}$ & $\begin{array}{l}1 \\
2 \\
2\end{array}$ & $\begin{array}{l}0.56 \\
0.62 \\
0.62\end{array}$ & $\begin{array}{l}30 \\
40 \\
40\end{array}$ & $\begin{array}{r}4 \cdot 46 \\
-0 \cdot 80 \\
1 \cdot 45\end{array}$ & $\begin{array}{r}2.32 \\
-0.80 \\
0.48\end{array}$ & $\begin{array}{r}2.14 \\
-0.80 \\
-1.13\end{array}$ & $\begin{array}{r}2.97 \\
-0.80 \\
0.27\end{array}$ \\
\hline \multicolumn{4}{|l|}{ Mean values } & $1 \cdot 70$ & 0.67 & 0.07 & 0.81 \\
\hline $37^{\circ} \mathrm{C}$ & $\begin{array}{l}1 \\
1 \\
2 \\
3 \\
4 \\
4 \\
5 \\
6\end{array}$ & $\begin{array}{l}0.90 \\
0.90 \\
0.44 \\
1 \cdot 10 \\
2 \cdot 0 \\
0.24 \\
1.00 \\
1 \cdot 25\end{array}$ & $\begin{array}{l}30 \\
30 \\
10 \\
40 \\
30 \\
30 \\
40 \\
35\end{array}$ & $\begin{array}{r}1.11 \\
-0.89 \\
9.32 \\
3.09 \\
3.50 \\
-5.00 \\
1.20 \\
-3.20\end{array}$ & $\begin{array}{r}1.22 \\
3.22 \\
0 \cdot 68 \\
5.55 \\
-1 \cdot 25 \\
-1 \cdot 10 \\
0.32\end{array}$ & $\begin{array}{c}2.67 \\
3.22 \\
0.91 \\
3.63 \\
- \\
0.00 \\
2.90 \\
-\end{array}$ & $\begin{array}{r}1.67 \\
1.85 \\
3.64 \\
4.09 \\
3.50 \\
-2.08 \\
2.40 \\
-1.44\end{array}$ \\
\hline \multicolumn{4}{|l|}{ Mean values } & $1 \cdot 14$ & 1.83 & $2 \cdot 22$ & 1.70 \\
\hline
\end{tabular}

It was of further interest to compare these results with whole semen with manometric measurements of oxygen consumption by washed cells. The results of these measurements made at $25^{\circ} \mathrm{C}$ and $37^{\circ} \mathrm{C}$ are shown in Table 3 . At $25^{\circ} \mathrm{C}$ oxygen uptake was negligible and at $37^{\circ} \mathrm{C}$ average $\mathrm{Zo}_{2}$ values were only slightly higher than those determined with whole semen. Although the variability in these measurements is larger, the average $\mathrm{Zo}_{2}$ values suggest a respiratory capacity for washed cells which is not significantly different from cells suspended in seminal plasma.

\section{Tracer experiments}

Text-fig. 1 plots the time course of ${ }^{14} \mathrm{CO}_{2}$ evolution resulting from metabolism of $\left[\mathrm{U}-{ }^{14} \mathrm{C}\right]$ glucose by spermatozoa in Norman-Johnson-Solution 2. 
Several considerations indicated that the $\mathrm{CO}_{2}$ is a product of sperm metabolism and not of bacterial contamination. First, the sigmoid curve is more simply interpretable as due to decline in metabolic activity of ageing spermatozoa rather than to respiratory activity of bacteria (exponential kinetics would be expected in the latter case). Second, we have tested a number of specimens for bacteria by plating on nutrient agar. In no case did bacteria exceed $10^{3}$ per ml which is too low to account for the $\mathrm{CO}_{2}$ produced. Finally, control experiments, in which isotope was added to cell-free media, showed that the suspending media contained no detectable $\mathrm{CO}_{2}$-producing activity.

Table 4 summarizes results of four experiments, using $\left[\mathrm{U}_{-}{ }^{14} \mathrm{C}\right]$ glucose as substrate, in which pooled sperm samples obtained on different days were used.

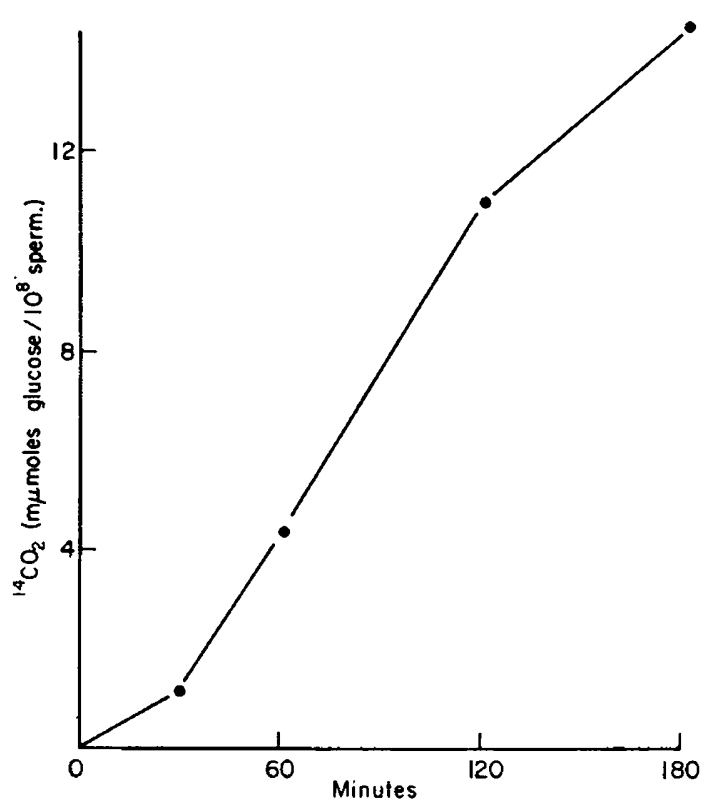

Text-FIG. 1. Time course of ${ }^{14} \mathrm{CO}_{2}$ production from $\left[\mathrm{U}^{-14} \mathrm{C}\right]$ glucose by human spermatozoa suspended in Norman-Johnson-Solution 2. Incubation flasks contained $10^{-3} \mathrm{M}$ $\left[\mathrm{U}-{ }^{14} \mathrm{C}\right]$ glucose $(275,000$ disintegrations $/ \mathrm{min} / \mu$ mole $)$ and $0.53 \times 10^{8}$ cells in a volume of $3 \mathrm{ml}$ at $\mathrm{pH} 7.7$ and $37^{\circ} \mathrm{C}$. The ordinate expresses the amount of labelled glucose converted to $\mathrm{CO}_{2} / 10^{8}$ cells.

$\mathrm{CO}_{2}$ production varied over a three- to four-fold range. This variation appears to be related to metabolic differences in the pooled specimens and not to experimental error. When measurements were made on the same pooled specimen, results were more reproducible and, as shown in Text-fig. 2, $\mathrm{CO}_{2}$ production was not significantly affected by a ten-fold change in cell concentration.

The rate of $\mathrm{CO}_{2}$ production by human spermatozoa is small (Terner, 1960, 1965). Considering the amount of lactate produced (about $1 \mu$ mole $/ 10^{8}$ cells/ hr; Peterson \& Freund, 1968), it can be estimated that less than $1 \%$ of the glucose metabolized is converted to $\mathrm{CO}_{2}$ which reflects the predominance of 


\section{TABLE 4}

${ }^{14} \mathrm{CO}_{2}$ PROdUGtion From $\left[\mathrm{U}^{14} \mathrm{C}\right.$ ] GLUCOSE $\left(10^{-3} \mathrm{M}\right)$ BY HUMAN SPERMATOZOA SUSPENDED IN NORMANJOHNSON-SOLUTION 2

\begin{tabular}{c|c|c}
\hline $\begin{array}{c}\text { Experiment } \\
\text { no. }\end{array}$ & $\begin{array}{c}\text { Sperm count } \\
\left(\times 10^{8}\right) \\
\text { per vial }\end{array}$ & $\begin{array}{c}{ }^{14} \mathrm{CO}_{2} \\
\left(\text { mumoles glucose } / 10^{8} \text { cells } / h r\right) *\end{array}$ \\
\hline 1 & 0.40 & 8.1 \\
2 & 0.35 & 13.4 \\
3 & 0.53 & 4.7 \\
4 & 0.30 & 2.8 \\
\hline \multicolumn{2}{l|}{ Mean value } & 7.25 \\
\hline
\end{tabular}

* Specific activity $=2.7 \times 10^{5}$ disintegrations $/ \mathrm{min} / \mu \mathrm{mole}$.

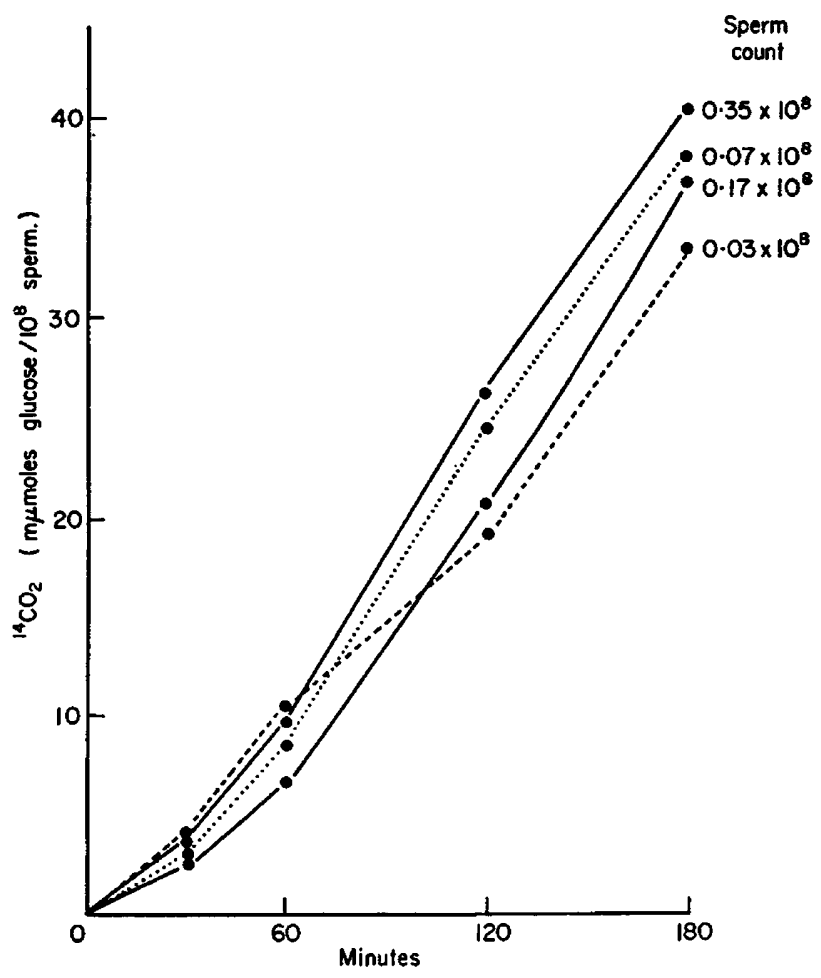

TeXT-FIG. 2. Effect of cell concentration on ${ }^{14} \mathrm{CO}_{2}$ production from $\left[\mathrm{U}^{-14} \mathrm{C}\right]$ glucose by human spermatozoa. Incubation conditions were the same as indicated in Text-fig. 1 . Each flask contained cells from the same pooled specimen which were washed and diluted to the indicated concentrations in Norman-Johnson-Solution 2. 
glycolytic pathways. Assuming a respiratory coefficient of 1 , the rate of $\mathrm{CO}_{2}$ production obtained $\left(7.25 \mathrm{~m} \mu \mathrm{moles} /\right.$ glucose $\left./ 10^{8} \mathrm{cells} / \mathrm{hr}\right)$ would correspond to a $\mathrm{Zo}_{2}$ of $0 \cdot 97$. However, if rates of ${ }^{14} \mathrm{CO}_{2}$ production from $\left[\mathrm{U}-{ }^{14} \mathrm{C}\right]$ glucose and $\left[6-{ }^{14} \mathrm{C}\right]$ glucose are compared, estimates of respiratory $\mathrm{CO}_{2}$ obtained with randomly labelled glucose may be high. This is demonstrated in Text-fig. 3 which shows ${ }^{14} \mathrm{CO}_{2}$ production from each isotope added to a washed cell suspension from the same pooled specimen. The suspension containing uniformly labelled glucose generated ${ }^{14} \mathrm{CO}_{2}$ at more than twice the rate of that

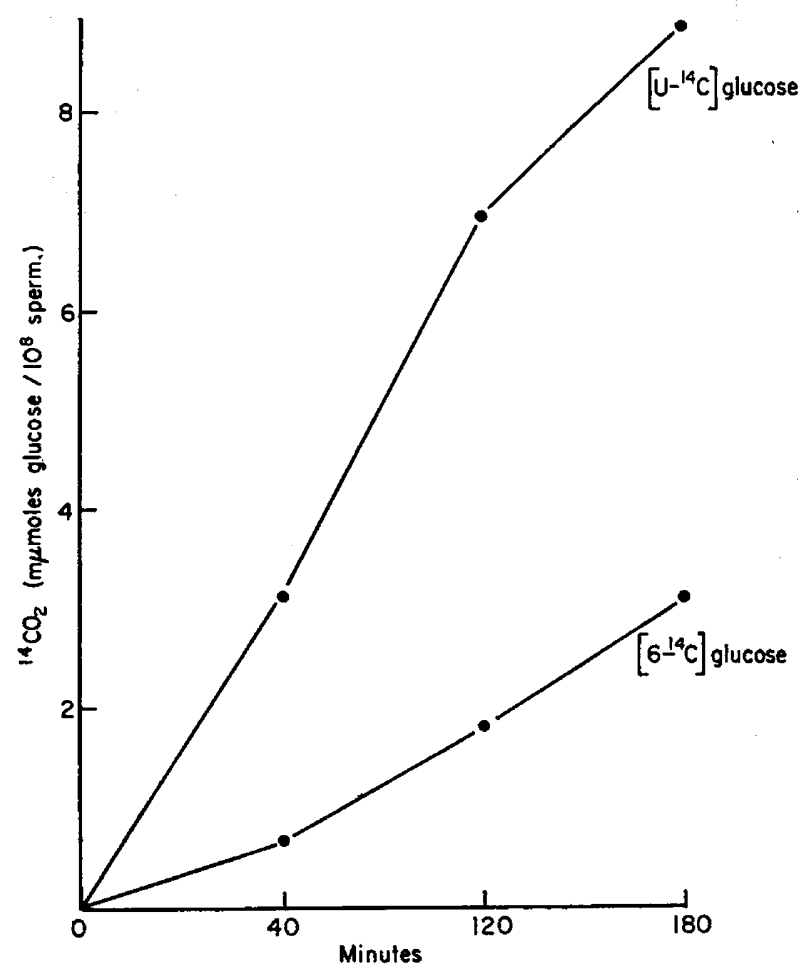

TeXT-FIG. 3. Comparison of the rates of ${ }^{14} \mathrm{CO}_{2}$ formation from $\left[\mathrm{U} \cdot{ }^{14} \mathrm{C}\right]$ glucose and $[6-14 \mathrm{C}]$ glucose by washed human sperm suspensions. Flasks contained $0.74 \times 10^{8}$ cells in buffered salts medium and $10^{-3} \mathrm{M}$ glucose. Specific activities were 275,000 disintegrations $/ \mathrm{min} / \mu$ mole $\left[\mathrm{U}-{ }^{14} \mathrm{C}\right] \mathrm{glucose}$ and 102,400 disintegrations $/ \mathrm{min} / \mu$ mole $\left[6-{ }^{14} \mathrm{C}\right]-$ glucose.

containing glucose labelled only in the carbon 6 position. This difference could be due to the presence of alternate pathways of $\mathrm{CO}_{2}$ production such as pyruvate dismutation which occurs in bull spermatozoa (Terner, 1959). This reaction generates $\mathrm{CO}_{2}$ by a non-oxidative mechanism involving carbon atoms 3 and 4 and apparently occurs under both anaerobic and aerobic conditions. Although this reaction in human spermatozoa must still be demonstrated, it would interfere with estimates of respiratory activity based solely on experiments with randomly labelled glucose. The conversion of $\left[6-{ }^{14} \mathrm{C}\right]$ glucose to ${ }^{14} \mathrm{CO}_{2}$ by washed human sperm cells, however, provides less equivocal radiochemical 
evidence than that previously reported that human spermatozoa are capable of true respiratory activity. Since it is not possible to estimate the extent to which each of the remaining carbon atoms of glucose is oxidized by the respiratory process, the data in Text-fig. 3 undoubtedly underestimate the actual rate of sperm respiration. Further, the radiochemical assay does not account for any endogenous respiratory activity which may also contribute to the overall rate.

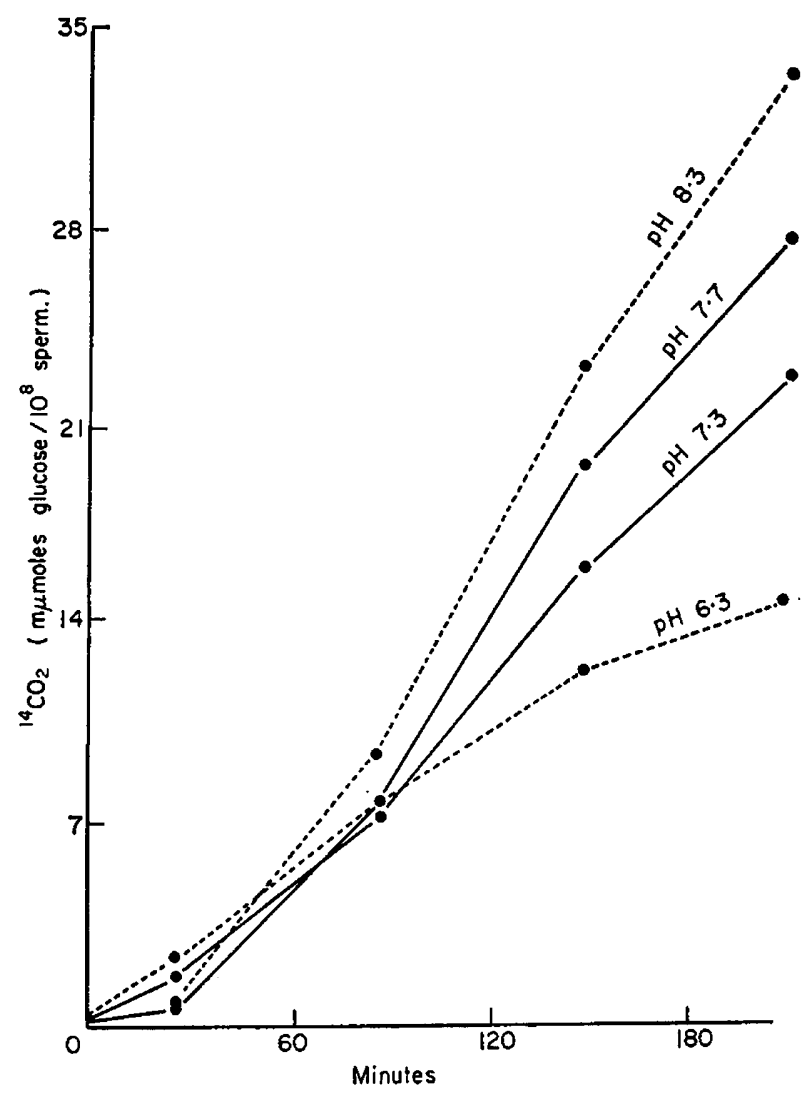

TexT-FIG. 4. Effect of $\mathrm{pH}$ on ${ }^{14} \mathrm{CO}_{2}$ production from $\left[\mathrm{U}-{ }^{14} \mathrm{C}\right]$ glucose by human spermatozoa suspended in Norman-Johnson-Solution 2. Cells were suspended in medium adjusted to the indicated $\mathrm{pH}$ values by the addition of dilute $(0.005 \mathrm{~N}) \mathrm{NaOH}$ or $\mathrm{HCl}$. Each flask contained $0.40 \times 10^{8}$ cells; other conditions were the same as in Text-fig. 1 .

Factors affecting ${ }^{14} \mathrm{CO}_{2}$ production from $\left[\mathrm{U}^{14}{ }^{14} \mathrm{C}\right]$ glucose

${ }^{14} \mathrm{CO}_{2}$ production from uniformly labelled glucose is affected by changes in hydrogen ion concentration (Text-fig. 4). The results were obtained by suspending aliquots of the pooled and washed cell suspension in Norman-Johnson-Solution 2 in which $\mathrm{pH}$ was adjusted by addition of dilute $\mathrm{HCl}$ or $\mathrm{NaOH}$. The rate of ${ }^{14} \mathrm{CO}_{2}$ evolution was maximal at the highest $\mathrm{pH}(8.3)$ but declined nearly two-fold when $\mathrm{pH}$ was reduced to 6.3. It has been noted (Blackshaw \& Emmens, 1951) that human sperm motility is enhanced in moderately alkaline media 
and it is possible that such increases in motility could be related to stimulation in respiratory activity.

The rate of labelled $\mathrm{CO}_{2}$ production is also affected by changes in the concentration of glucose (Text-fig. 5 ). ${ }^{14} \mathrm{CO}_{2}$ formation is maximum at a glucose concentration of $10^{-3} \mathrm{M}$. A ten-fold further increase in concentration did not increase respiration but instead slightly decreased the rate. Other experiments have shown that lactate production from glucose also does not increase above a glucose concentration of $10^{-3} \mathrm{M}$. These results might suggest that the oxidative process is limited by the glycolytic rate at high $\left(>10^{-3} \mathrm{M}\right)$ glucose concentrations. However, when dinitrophenol is added to these cell

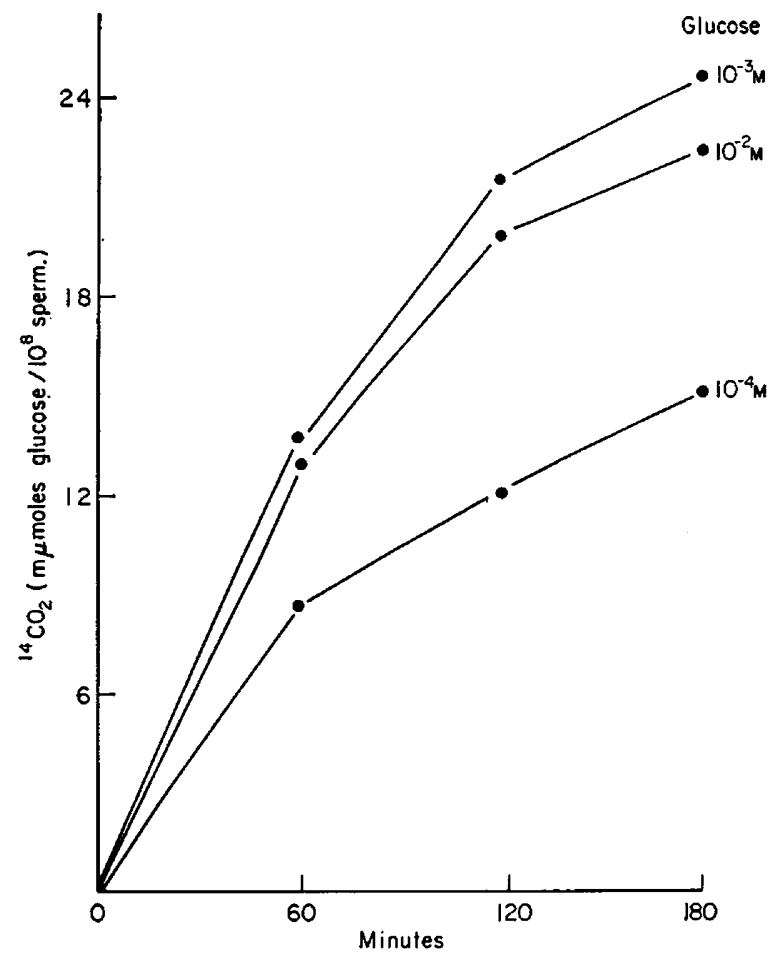

TEXT-FIG. 5. Effect of glucose concentration on the rate of ${ }^{14} \mathrm{CO}_{2}$ production from $\left[\mathrm{U}-{ }^{14} \mathrm{C}\right]$ glucose by human spermatozoa. Flasks contained $0.47 \times 10^{8}$ cells in salts medium buffered at $\mathrm{pH} 7 \cdot 4$. [U-14 C]Glucose was added at the indicated concentrations. Specific activities were $5 \times 10^{6}$ disintegrations $/ \mathrm{min} / \mu \mathrm{mole}\left(10^{-4} \mathrm{M}\right), 5 \times 10^{5}$ disintegrations $/ \mathrm{min} / \mu \mathrm{mole}\left(10^{-3} \mathrm{M}\right)$ and $5 \times 10^{4}$ disintegrations $/ \mathrm{min} / \mu \mathrm{mole}\left(10^{-2} \mathrm{M}\right)$.

suspensions, glucose oxidation is almost doubled while the glycolytic rate is only slightly increased $(10 \%)$ (Peterson \& Freund, 1968). This would indicate that oxidation is limited by phosphate acceptors rather than the availability of glycolytic end products at saturating glucose concentrations. We attempted to test this possibility by determining the effects of added adenine nucleotides and inorganic phosphate on labelled glucose oxidation. ADP and 5'AMP, added at $1 \mathrm{~mm}$ had little effect on ${ }^{14} \mathrm{CO}_{2}$ production while high concentrations of inorganic phosphate inhibited the rate (Text-fig. 6). All three compounds 
had little or no effect on the glycolytic rate, but it is conceivable that these results reflect in part the inability of the charged nucleotides to penetrate the cell membrane. It may be possible to obtain more conclusive results by using procedures which alter membrane permeability before adding test substances.

We have also initiated experiments designed to determine the metabolic fate of glucose added to sperm cell suspensions. Most of the glucose is metabolized to lactate with only a small fraction being converted to carbon dioxide but there is also a fraction that is retained by cells. This is shown in Text-fig. 7 where total glucose taken up by washed cell suspensions and glucose converted

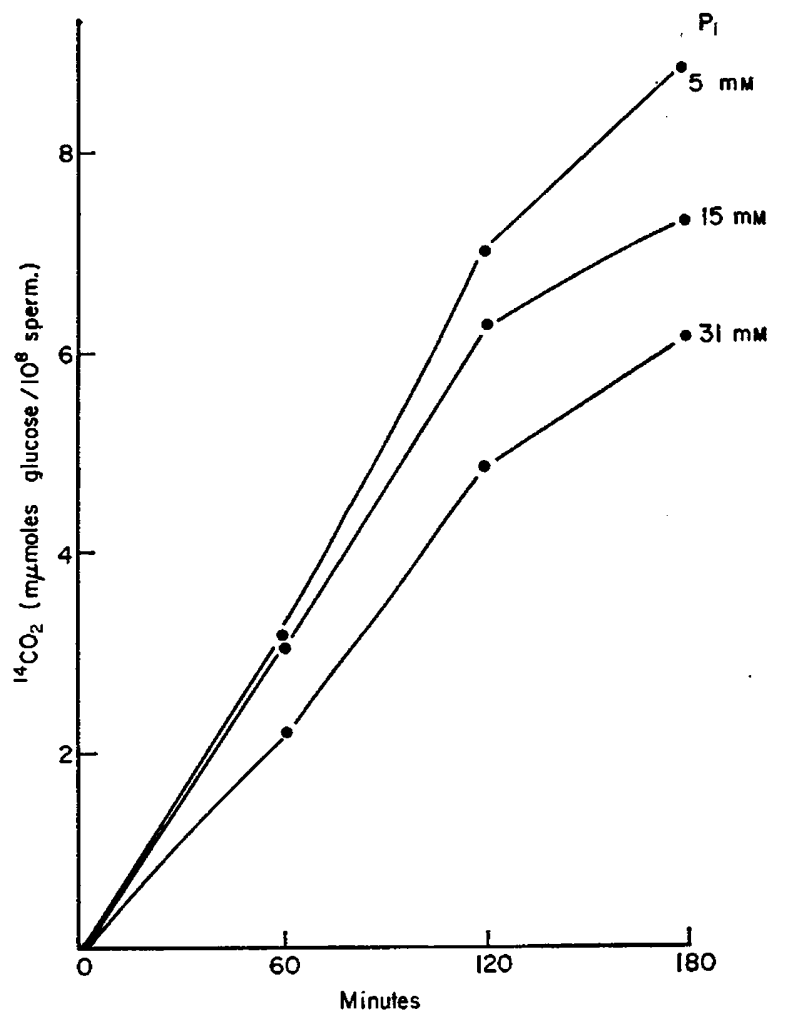

TEXT-FIG. 6. Effect of inorganic phosphate concentration on the rate of ${ }^{14} \mathrm{CO}_{2}$ production from $\left[\mathrm{U}-{ }^{14} \mathrm{C}\right]$ glucose by human sperm cells. Flasks contained $0.74 \times 10^{8}$ cells suspended in phosphate buffered medium. Isomolarity was maintained in each flask by the subtraction of osmolar equivalents of $\mathrm{NaCl}$ for each increment in phosphate ion concentration. The concentration of glucose was $10^{-3} \mathrm{M}(275,000$ disintegrations/min/ $/ \mu \mathrm{mole})$.

to acid-insoluble cellular compounds has been followed, using the technique of rapid Millipore filtration. The difference in the two curves represents uptake into acid-soluble compounds. The figure shows that uptake into the acidinsoluble pool increased slowly and reached a maximum after $60 \mathrm{~min}$. This suggests a relatively slow turnover of a portion of the compounds making up the pool. Thereafter, radio-activity in the soluble pool declined and after 
120 min most of the radio-activity retained by cells was incorporated into acidinsoluble material. Since only a small portion of the exogenous substrate was utilized, the decrease in total glucose uptake indicates an increased leakage of pool constituents out of the cell. This may be related to the decline in motility during a particular experiment. Uptake into acid-insoluble material began almost immediately and continued to increase throughout the experiment. At the end of the 1st hour, accumulation into acid-insoluble material represented nearly one third of total radio-activity. Since protein and nucleic acid synthesis is negligible, most of the insoluble material is presumably lipid. This is supported by experiments which showed that labelled glucose can be converted by human spermatozoa into the glycerol moiety of cellular glycerides (Terner, 1966). Our experiments suggest that such incorporation is very rapid and that a considerable portion of the glucose retained by cells is channelled

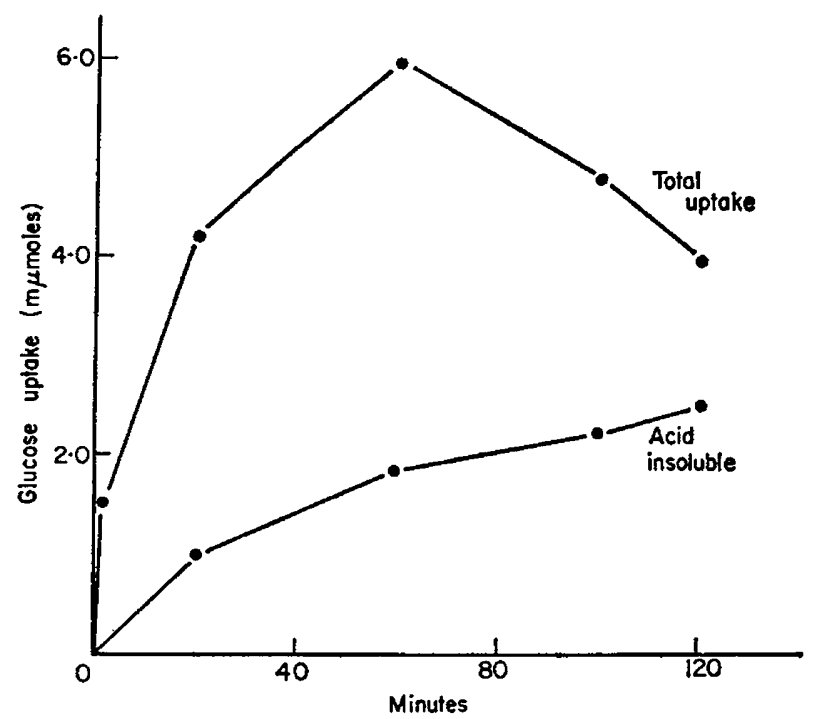

TEXT-FIG. 7. Total uptake and uptake into acid-insoluble compounds of $\left[\mathrm{U}-{ }^{14} \mathrm{C}\right]$ glucose by human sperm cells. Flasks contained $1.10 \times 10^{8}$ cells in buffered salts medium and $10^{-3} \mathrm{M}$ glucose (445,000 disintegrations/min/ $\mu$ mole). Total uptake and uptake into acid-insoluble. compounds were followed by the rapid Millipore filtration technique (Methods).

into this pathway. In a separate experiment, it was observed that acid-insoluble material formed continued to increase as glucose concentration was increased from $10^{-4} \mathrm{M}$ to $10^{-2} \mathrm{M}$. At higher glycolytic rates, larger amounts of carbohydrates are converted to lipid which may serve as a source of energy in less nutritional environments. The experiment shown in Text-fig. 7 gives no information about the turnover of acid-insoluble (lipid) material. Uptake into lipid compounds may represent re-synthesis of lipid lost to catabolic processes or a net accumulation of cellular lipid. The rapid filtration technique, however, provides a method to test these alternatives. 


\section{DISGUSSION}

In this study both manometric and radiochemical techniques have been used to estimate respiration by human spermatozoa suspended in seminal plasma and in artificial media. Respiration is low and rates rarely exceed 1 to $2 \mu \mathrm{l} / 10^{8}$ cells $/ \mathrm{hr}$. This work confirms the manometric observations by MacLeod (1941, 1943) who was unable to detect an appreciable oxygen consumption by spermatozoa suspended in artificial media. The usefulness of the manometric method for measurement of oxygen uptake by human semen depends on an accurate estimate of uptake by the seminal plasma and, because respiration rates are small, the use of pooled specimens with high cell concentrations. Oxygen uptake by plasma is not only large (representing from 80 to $90 \%$ of total uptake by semen) but also varies from specimen to specimen. Variations in oxygen uptake by seminal plasma and by spermatozoa might be expected from known day-to-day differences in semen quality in pooled and individual specimens. Changes in sperm concentration, motility, morphology and seminal plasma volume have been shown in specimens from the same individual on different days (Freund, 1962). It is not unlikely, therefore, that such specimens will also show variation in metabolic activity. Obviously, similar variation will occur in pooled specimens (as has been shown by Freund \& Wiederman, 1966) since such specimens are often obtained from different donors on different days.

The high $\mathrm{Zo}_{2}$ values for human semen reported by Shettles (1940) are the result of failing to correct for plasma oxygen uptake. This also seems true of the results reported by Davis \& McCune (1950), where plasma oxygen uptake was determined in only two specimens. Since uptake in these specimens was appreciably smaller than the average uptake by semen, the authors attributed most of the uptake by semen to sperm respiration. This is hardly justifiable in view of the variation in plasma volume and plasma oxygen uptake that occurs among different specimens. Clearly erroneous $\mathrm{Zo}_{2}$ values will also result if an average value for plasma uptake is subtracted from total oxygen consumption. This appears to have been done by Williams \& Hamner (1963) and may explain the unusually high sperm respiration rates reported.

There appears to be little difference in respiratory rates of spermatozoa in semen and washed cells suspended in Norman-Johnson-Solution 2 as determined by manometric measurements, and the rate of conversion of labelled glucose to $\mathrm{CO}_{2}$. The average conversion rate of uniformly-labelled glucose to carbon dioxide $\left(7.25 \mathrm{~m} \mu\right.$ moles $/ 10^{8}$ cells $\left./ \mathrm{hr}\right)$ falls between the two markedly different values reported earlier by Terner (1965) for similar experiments (19.6 $\mathrm{m} \mu$ moles $/ 10^{8}$ cells $/ \mathrm{hr}, 1960 ; 3.82 \mathrm{~m} \mu$ moles $/ 10^{8}$ cells $/ \mathrm{hr}$ ) 1965). These values correspond to a range of $\mathrm{CO}_{2}$ production between 0.5 and $1.8 \mu \mathrm{l}$ $\mathrm{CO}_{2} / 10^{8}$ cells $/ \mathrm{hr}$ and, assuming a respiratory quotient of unity, are in good agreement with the manometric estimates of oxygen consumption. The lower rate of $\mathrm{CO}_{2}$ formation from $\left[6-{ }^{14} \mathrm{C}\right]$ glucose, however, suggests that a portion of the labelled $\mathrm{CO}_{2}$ arising from the metabolism of uniformly labelled glucose may be due to non-respiratory pathways. This observation together with a lack of knowledge concerning the contribution of endogenous metabolism to $\mathrm{CO}_{2}$ 
production places a degree of uncertainty as to how closely labelled $\mathrm{CO}_{2}$ formation is related to oxygen uptake. The results obtained with $\left[6-{ }^{14} \mathrm{C}\right]-$ glucose suggest a minimum rate of respiration and these isotope experiments support the conclusion that the respiration of washed cells is small and not significantly different from the respiration of spermatozoa in semen. Questions regarding the reason for this small respiration remain to be answered. Evidence has recently been presented (Nevo, 1966) that human spermatozoa respire in the absence of exogenous substrate and that this endogenous respiration supports motility. The mitochondrial apparatus may therefore serve in those circumstances where exogenous hexose is unavailable or in low supply (for example, sperm passage through the female reproductive tract). Presumably, lipid reserves support this respiration.

\section{ACKNOWLEDGMENTS}

This investigation was supported by Grant No. HD-00488-09 from the National Institute of Child Health and Human Development, National Institutes of Health, U.S. Public Health Service. The authors gratefully acknowledge the technical assistance of Mrs Gloria Edwards and Miss Ollie Brown. The junior author is a Career Scientist of the Health Research Council of the City of New York (I-218).

\section{REFERENCES}

Baggioline, M. \& Bickel, M. (1966) A new type of incubation apparatus for the determination of metabolically produced ${ }^{14} \mathrm{CO}_{2}$. Analyt. Biochem. 14, 290.

Blackshaw, A. W. \& Emmens, C. W. (1951) The interaction of $\mathrm{pH}$, osmotic pressure and electrolyte concentration on the motility of ram, bull and human spermatozoa. F. Physiol., Lond. 114, 16.

BritTen, R. J., Roberts, R. B. \& French, E. F. (1955) Amino acid absorption and protein synthesis in Escherichia coli. Proc, natn. Acad. Sci. U.S.A. 41, 863.

Davis, E. M. \& McCune, W. W. (1950) Metabolism of human spermatozoa in semen. Fert. Steril. 1, 158.

FREUND, M. (1962) Interrelationships among the characteristics of human semen and factors affecting semen specimen quality. F. Reprod. Fert. 4, 143.

FREUND, M. (1963) Effect of frequency of emission on semen output and an estimate of daily sperm production in man. F. Reprod. Fert. 6, 269.

FreUnd, M. \& CAROL, B. (1964) Factors affecting haemocytometer counts of sperm concentration in human semen. 7. Reprod. Fert. 8, 149.

FreUnd, M. \& MAcLeod, J. (1958) Effect of addition of fructose and of glucose on the fructolysis and motility of human semen. F. appl. Physiol. 13, 506.

Freund, M. \& Wiederman, J. (1966) Factors affecting the dilution, freezing and storage of human semen. F. Reprod. Fert. 11, 1.

MacLeod, J. (1941) The metabolism of human spermatozoa. Am. F. Physiol. 132, 193.

MACLEOD, J. (1943) The role of oxygen in the metabolism and motility of human spermatozoa. $\mathrm{Am} . \mathcal{F}$. Physiol. 138, 512.

MACLeOD, J. \& FREUnd, M. (1958) Influence of spermatozoal concentration and initial fructose level on fructolysis in human semen. $\mathcal{F}$. appl. Physiol. 13,501.

ManN, T. (1951) Studies on metabolism of semen. 7. Cytochrome in human spermatozoa. Biochem. F. $48,386$.

Nevo, A. (1966) Relation between motility and respiration in human spermatozoa. J. Reprod. Fert. $11,19$.

Norman, G. (1964) Further studies on the preservation of mammalian sperm at variable temperatures. Proc. Vth int. Congr. Anim. Reprod., Trento, p. 269.

Peterson, R. N. \& Freund, M. (1968) Glycolysis by suspension of washed human spermatozoa. Fedn Proc. Fedn Am. Socs Exp. Biol. 27, 285. 
Peterson, R. N., Freund, M. \& Gilmont, R. (1967) Measurement of low rates of oxygen consumption with a horizontal capillary-differential syringe manometer. Proc. Soc. exp. Biol. Med. $125,645$.

Ross, V., Miller, E. G. \& Kurzrox, R. (1941) Metabolism of human sperm. Endocrinology, 28, 885.

ROTHSCHILD, LORD (1960) The heat production of human spermatozoa and seminal plasma with comparative observations on bull semen. Proc. R. Soc. B, 152, 298.

ShettLes, L. B. (1940) The respiration of human spermatozoa and their response to various gases and low temperatures. Am. F. Physiol. 128, 408.

Terner, C. (1959) The effects of 2,4-dinitrophenol and $p$-nitrophenol on the aerobic and anaerobic metabolism of bull spermatozoa. Biochim. biophys. Acta, 36, 479.

Terner, C. (1960) Oxidation of exogenous substrate by isolated human spermatozoa. Am. F. Physiol. $198,48$.

TERnER, C. (1965) Oxidative and biosynthetic utilization by human spermatozoa of a metabolite of the female reproductive tract. Nature, Lond. 208, 1115.

Terner, C. (1966) Biosynthesis of lipids by human and fish spermatozoa. Am. 7. Physiol. 210, 615.

WHITE, I. G. (1954) The effect of some seminal constituents and related substances on diluted mammalian spermatozoa. Aust. J. biol. Sci. 7, 379.

Williass, W. W. \& Hamner, C. E. (1963) Stimulation of respiration of rabbit, human and cock spermatozoa by light and certain chemicals. F. Reprod. Fert. 6, 235. 